\title{
Researches on the Diffusion Phenomena in the Thermo-Chemical Treatment of Oxy-nitrocarburizing of Some Grey Cast Irons
}

\author{
GINA MIHAELA SICOE* \\ University of Pitesti, 1Targul din Vale, 110040, Piresti, Romania
}

\begin{abstract}
The thermo-chemical treatment of oxy-nitrocarburizing consists in the enrichment of materials in $\mathrm{C}, \mathrm{N}$ and $O$ in order to improve the physico-mechanical properties and the use of the materials. This leads to the increase in exploitation life, the increase of wear resistance, galling, corrosion, and slight erosion. The research presented in this article followed the study of the application of this treatment and the results obtained on pearlitic grey cast iron with different chemical compositions, domain in which there are few experimental results published. The results obtained on a number of 10 samples, presented in the article, highlighted the good compatibility of these materials with the thermo-chemical treatment of oxynitrocarburizing, obtaining on the surface some white layers which give good anti-corrosive properties, similar to those obtained on steel. There was no correlation between the depth of the white layer and the chemical composition of the studied cast iron. It was also emphasized that the depth of nitrogen diffusion is influenced by the chemical composition of the studied materials which is directly proportional to carbon equivalent $\left(C_{\text {eq }}\right.$ of cast iron.
\end{abstract}

Keywords: oxy-nitro-carburizing, pearlitic grey cast iron, white layer

The study of the oxy-nitrocarburizing process applied to cast iron represents a novelty, there is not enough data described in the bibliographic papers studied. In this context, it is considered that the experimental research and the processing of the results obtained in a batch of 10 grey cast iron samples that have been subjected to oxynitrocarburizing treatment make a particular contribution to the development of this type of treatment for new applications.

For this study a large number of experimental determinations were performed, which were analyzed with laboratory techniques and finally the results were interpreted to establish correlations between the different sizes studied.

\section{Experimental part}

Oxy-nitrocarburizing is an enrichment treatment in $\mathrm{C}, \mathrm{N}$ and $O[4,9]$ applied to materials in which the growth of exploitation life [1], the growth of wear resistance, galling [11], corrosion, gentle erosion are sought. It is also sought to reduce technological consumption and replace salt baths, and even galvanic baths. Because the duration of the process is very low (4 to $8 \mathrm{~h}$ ), oxy-nitrocarburizing is recommended instead of normal nitration in natural gas [10]. At temperatures of $570-600^{\circ} \mathrm{C}$ in the case of oxynitrocarburizing ( $\mathrm{Fe}-\mathrm{N}-\mathrm{C}$ system), the phase domain $\varepsilon$ (which confers corrosion resistance) [4] is wider than with the usual nitration (Fe - N system) [4], it is possible to obtain this phase in lower temperature conditions and nitrogen concentration as compared to the $\mathrm{Fe}$ - $\mathrm{N}$ system, the layer obtained may consist of one or more phases [5], depending on the $\mathrm{N}$ concentrations and temperature, the chemical composition of steel or cast iron.

The research published in technical literature demonstrated the existence of complex phases of the type à, with a compact crystalline network which, depending on the cementing environment, may be nitrides, nitrocarbides or oxy-nitro-carbides[4, 8].

On the surface of oxy-nitrocarburized parts a white layer [14] is formed, which has a fine structure, resembling a lot to the chemically deposited layer made of vapors, presented as a continuous amorphous layer. It has anticorrosive properties.

The active elements that diffuse in the superficial layer are nitrogen, oxygen and carbon. Due to the fact that the nitrocarburizing process takes place at low temperature, the two main elements, nitrogen and carbon, behave differently from the point of view of interaction with the superficial layer. Nitrogen diffuses inside the superficial layer, while carbon, unable to enter the diffusion layer, remains in the maximum concentration in the compound layer [6].

For this study, 10 samples of grey cast iron with the chemical composition shown in table 1 were used.

\begin{tabular}{|c|c|c|c|c|c|c|}
\hline $\begin{array}{c}\text { Sample } \\
\text { No. }\end{array}$ & $\begin{array}{c}\text { Sample } \\
\text { Code }\end{array}$ & $\begin{array}{c}\mathrm{C} \\
{[\%]}\end{array}$ & $\begin{array}{c}\mathrm{Si} \\
{[\%]}\end{array}$ & $\begin{array}{c}\mathrm{Mn} \\
{[\%]}\end{array}$ & $\begin{array}{c}\mathrm{P} \\
{[\%]}\end{array}$ & $\begin{array}{c}\mathrm{C}_{\text {\%q }} \\
{[\%]}\end{array}$ \\
\hline 1 & OCN1365 & 3.03 & 1.97 & 0.58 & 0.12 & 3.73 \\
\hline 2 & OCN 1375 & 3.05 & 2.15 & 0.58 & 0.13 & 3.81 \\
\hline 3 & OCN 1584 & 2.80 & 1.54 & 0.53 & 0.10 & 3.35 \\
\hline 4 & OCN 1600 & 2.91 & 1.81 & 0.56 & 0.096 & 3.55 \\
\hline 5 & OCN 2933 & 3.12 & 1.94 & 0.68 & 0.088 & 3.8 \\
\hline 6 & OCN 3142 & 2.93 & 1.70 & 0.55 & 0.054 & 3.51 \\
\hline 7 & OCN 3160 & 3.42 & 2.26 & 0.52 & 0.087 & 4.2 \\
\hline 8 & OCN 3241 & 3.20 & 2.10 & 0.63 & 0.07 & 3.92 \\
\hline 9 & OCN 3437 & 3.46 & 2.37 & 0.37 & 0.019 & 4.26 \\
\hline 10 & OCN 3446 & 2.94 & 1.83 & 0.65 & 0.075 & 3.58 \\
\hline
\end{tabular}

Table 1

CHEMICAL COMPOSITION [\%] OF SAMPLESUSED

*email: gina.sicoe@upit.ro; gina_boicea@yahoo.com, Phone: +40752222303 


\begin{tabular}{|c|c|c|c|c|}
\hline $\begin{array}{c}\text { Temperature } \\
{\left[{ }^{\circ} \mathrm{C}\right]}\end{array}$ & $\begin{array}{c}\text { Cycle time } \\
{[\mathrm{h}]}\end{array}$ & $\begin{array}{c}\mathrm{N}_{2} \\
{[\mathrm{Nm} 3 / \mathrm{h}]}\end{array}$ & $\begin{array}{c}\mathrm{NH}_{3} \\
{[\mathrm{Nm} 3 / \mathrm{h}]}\end{array}$ & $\begin{array}{c}\mathrm{CO}_{2} \\
{[\mathrm{Nm} 3 / \mathrm{h}]}\end{array}$ \\
\hline 570 & 8 & $0.4 \pm 0.1$ & $0.4 \pm 0.1$ & $0.3 \pm 0.1$ \\
\hline
\end{tabular}

Table 2

PARAMETERS OF THE THERMO-CHEMICAL PROCESS

Parameters of the thermo-chemical treatment of oxynitrocarburizing $[5,12]$ applied are shown in table 2.

The metallographic structure of the samples after thermo-chemical treatment is shown in figure 1-10; All samples have lamellar graphite in the Pearlite matrix.

The Nitrogen diffusion profile (GDOS-S2), as well as the depth of white layer (GDOS-S1) [7] were analyzed with the GD-OES (Glow Discharge - Optical Emission Spectrometry) spectrometer $[5,13]$. So, each sample was analyzed with the GD-OES spectrometer (JY 5000RF spectral apparatus), using an exposure time of up to $550 \mathrm{~s}$.

Surface spectral analysis by means of GD-OES technique allowed determination of nitrogen diffusion depth and also the determination of the diffusion curve profile, (fig.1120).

Through the erosion [3] phenomenon there were obtained results on the concentration of chemical elements of interest, carbon and nitrogen, on a depth of up to 36 microns. Since usual depths of white layers are of 2 microns and the diffusion profile tends to zero in the range of 30-50 microns (see the diffusion curve from figure 11$20)$, the results are considered satisfactory.

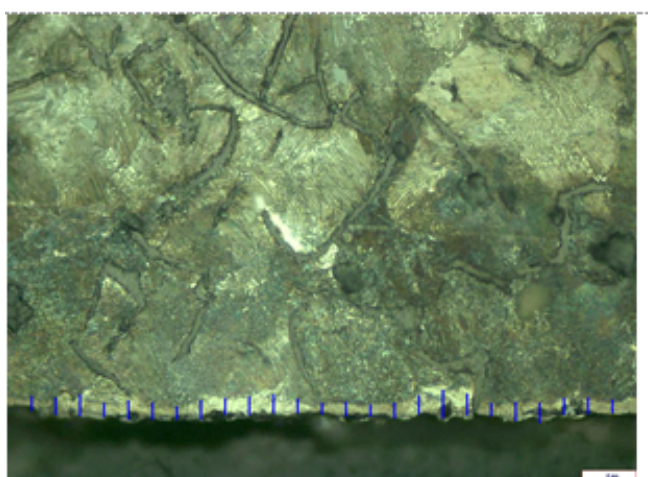

Fig.1. Metallographic structure of sample 1365

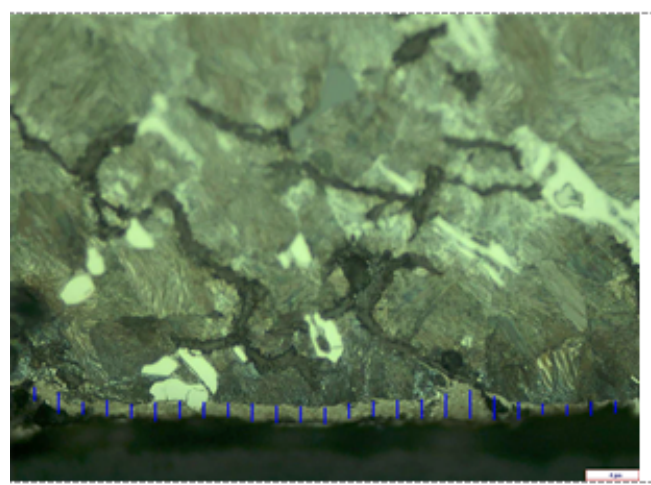

Fig.3. Metallographic structure of sample 1584

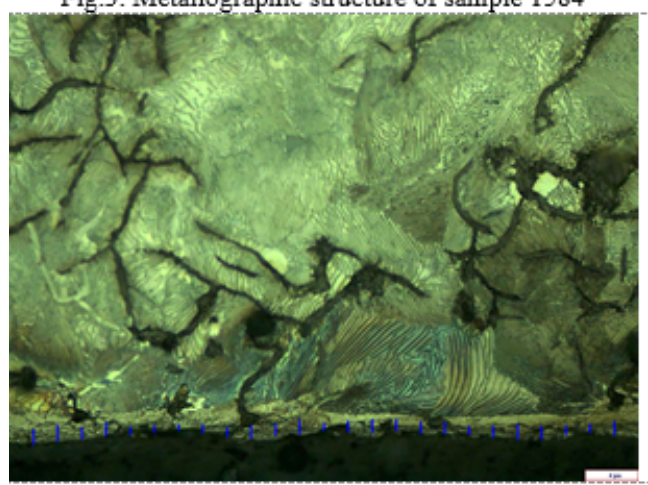

Fig.5. Metallographic structure of sample 2933

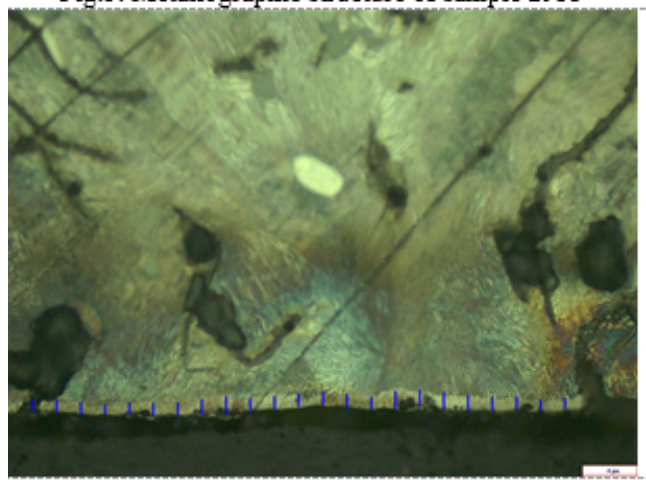

Fig.7. Metallographic structure of sample 3160

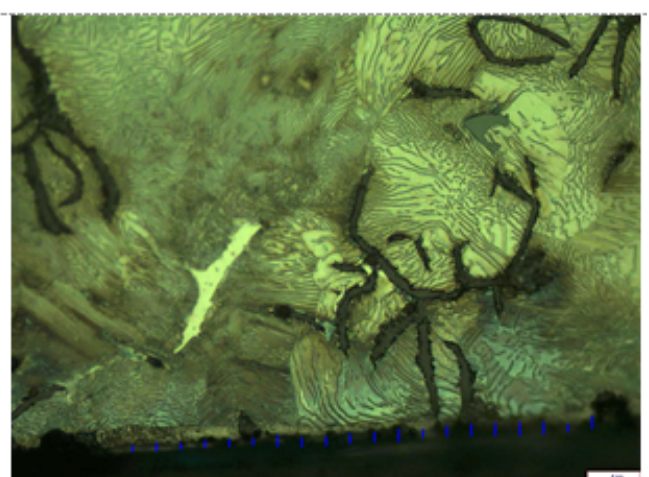

Fig.2. Metallographic structure of sample 1375

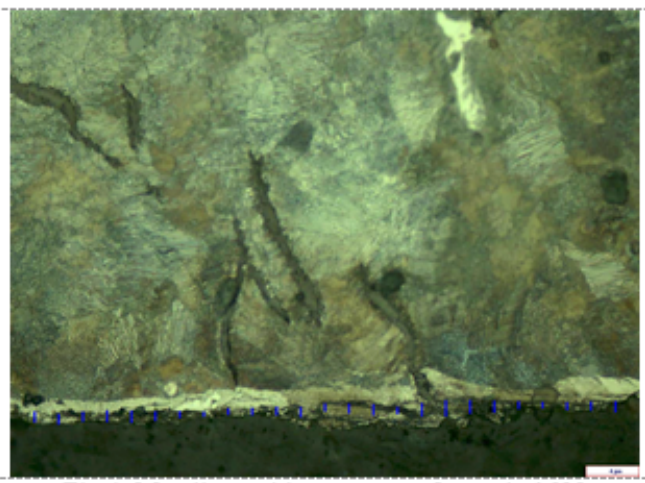

Fig.4. Metallographic structure of sample 1600

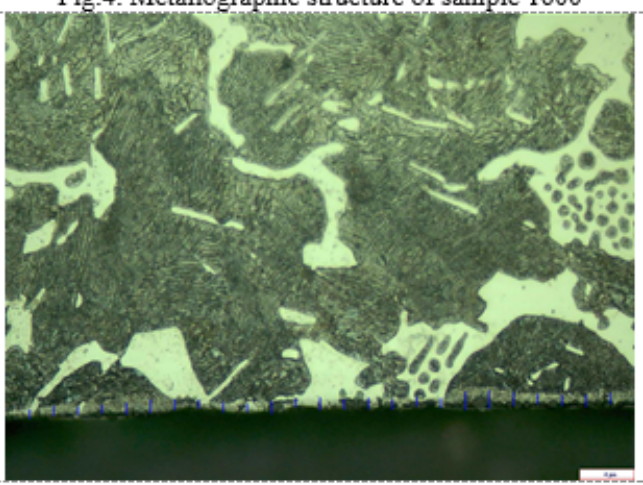

Fig.6. Metallographic structure of sample 3142

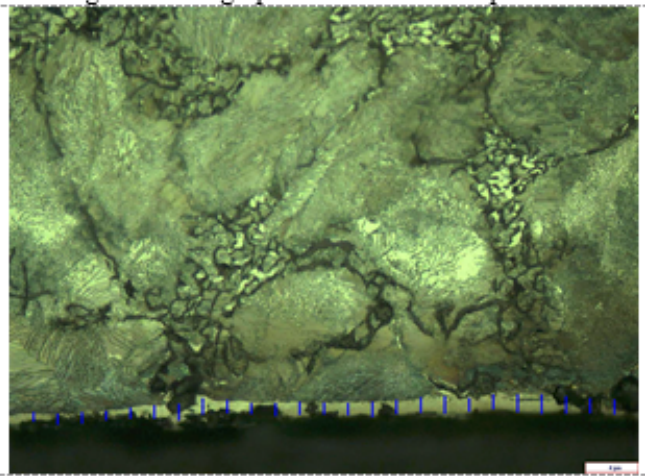

Fig.8. Metallographic structure of sample 3241 


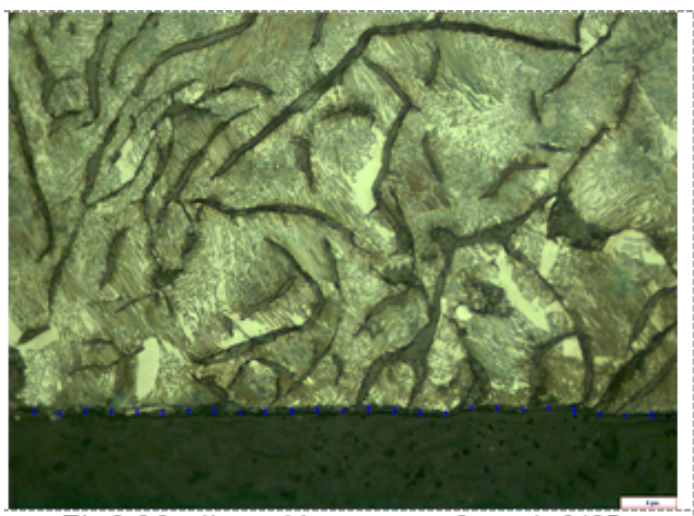

Fig.9. Metallographic structure of sample 3437

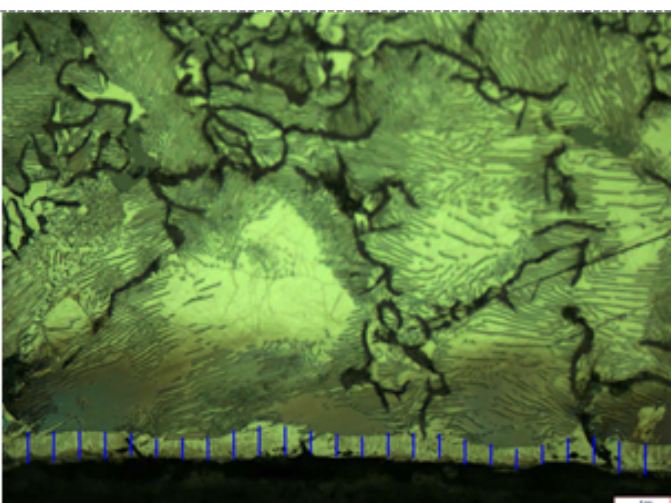

Fig.10 Metallographic structure of sample 3446

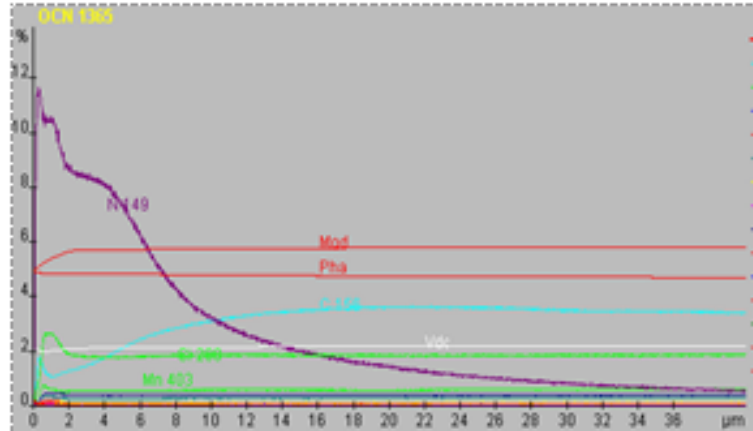

Fig.11. Results of the spectral analysis for sample 1365
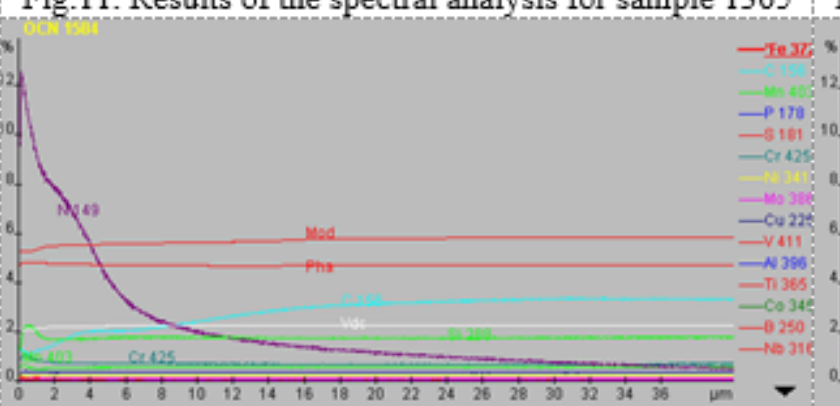

Fig.13. Results of the spectral analysis for sample 1584

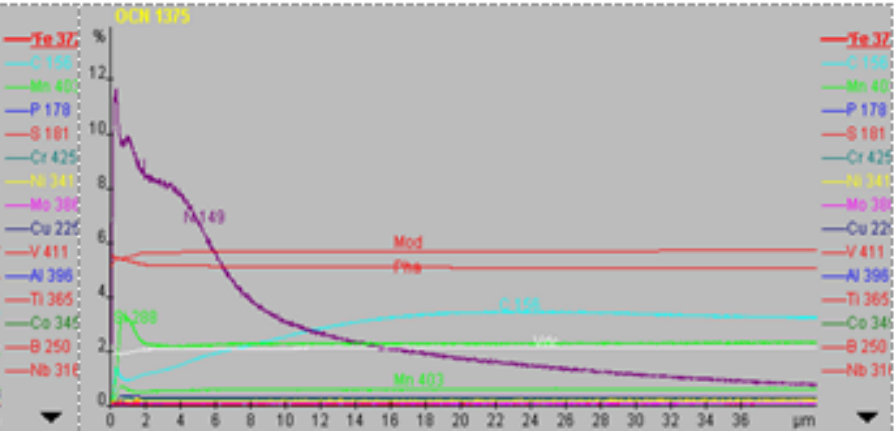

Fig.12. Results of the spectral analysis for sample 1375

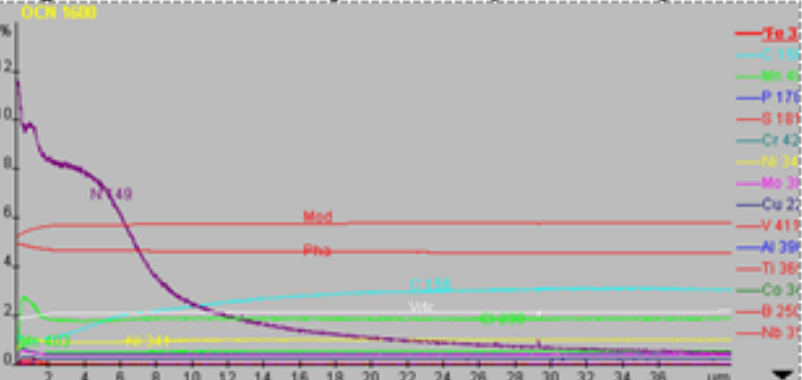

Fig.14. Results of the spectral analysis for sample 1600

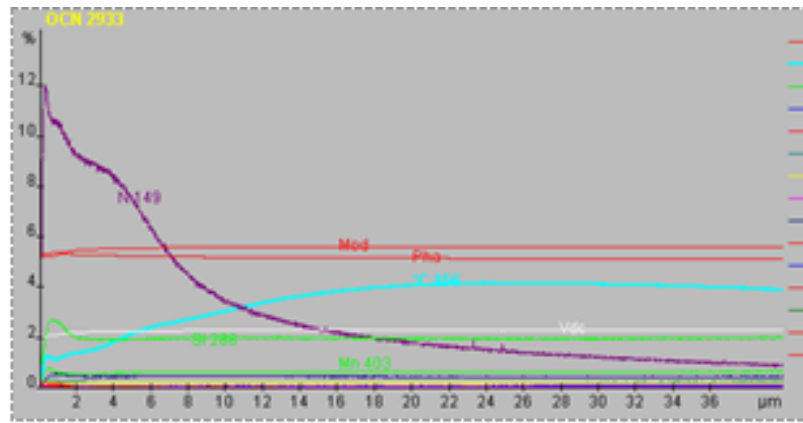

Fig.15. Results of the spectral analysis for sample 2933

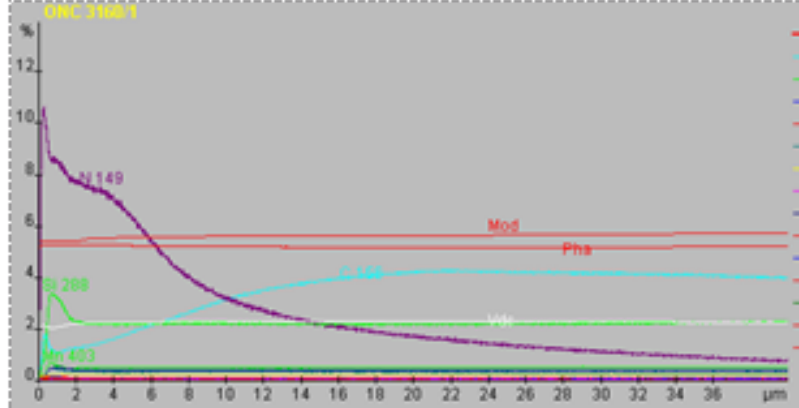

Fig.17. Results of the spectral analysis for sample 3160

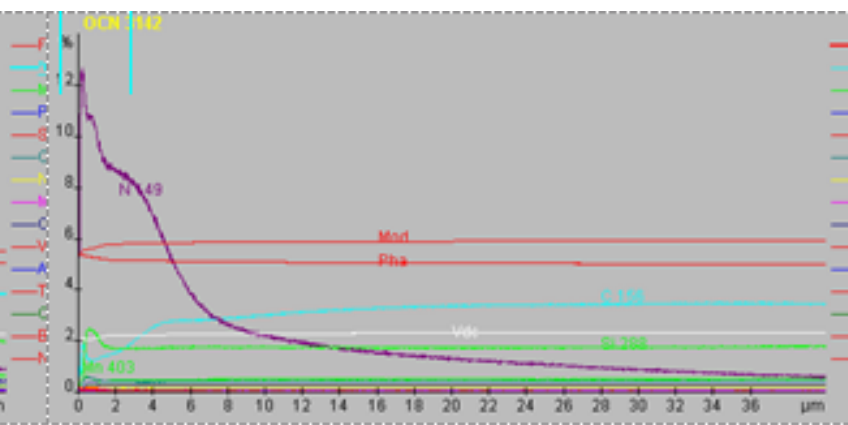

Fig.16. Results of the spectral analysis for sample 3142

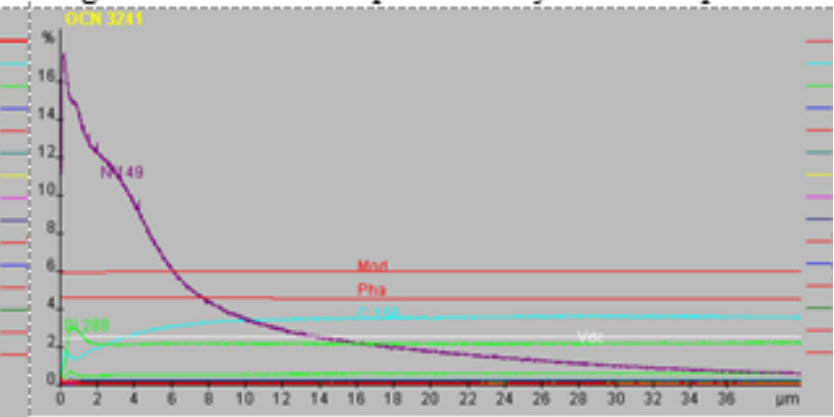

Fig.18. Results of the spectral analysis for sample 3241 


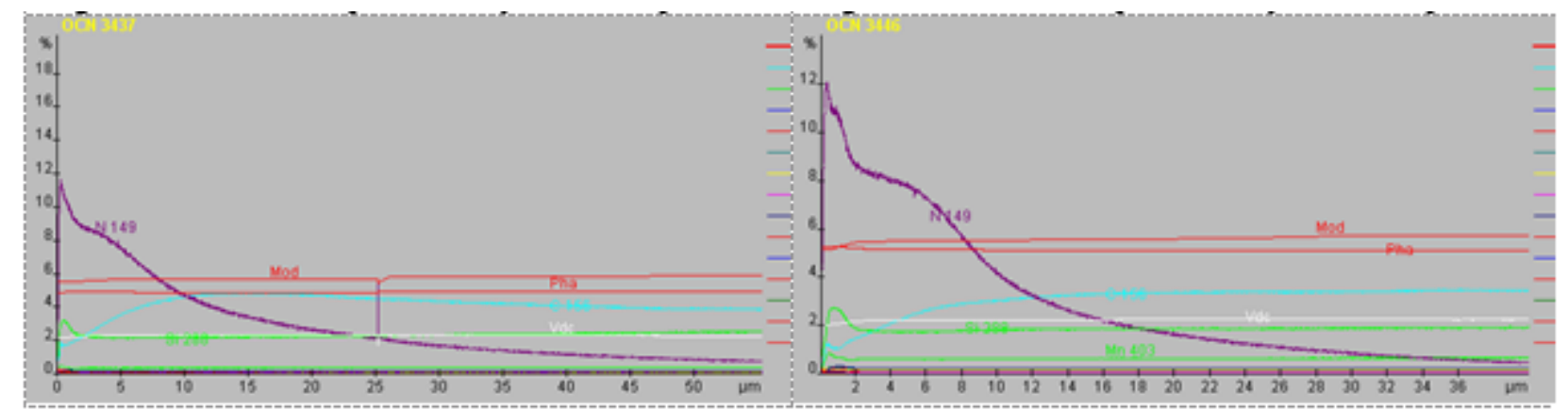

Fig.19. Results of the spectral analysis for sample 3437 $\quad$ Fig.20. Results of the spectral analysis for sample 3446

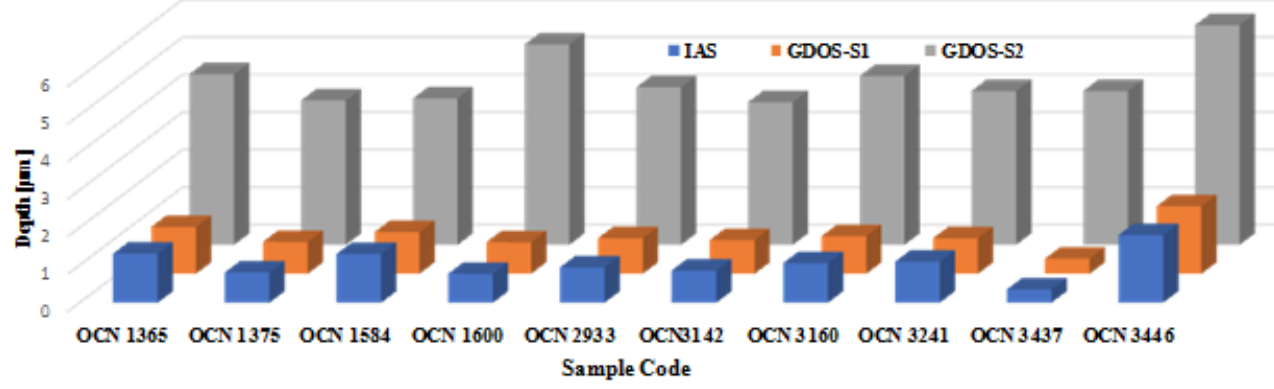

Fig.21. The depth of white layer (IAS and GDOS-S1) and Nitrogen diffusion (GDOS-S2)

\begin{tabular}{|c|c|c|c|c|}
\hline & & & & \\
\hline OCN 1365 & 1.305 & 1.25 & 4.55 & 25.0 \\
\hline OCN 1375 & 0.803 & 0.85 & 3.85 & 33.0 \\
\hline OCN 1584 & 1.297 & 1.11 & 3.9 & 22.9 \\
\hline OCN 1600 & 0.769 & 0.84 & 5.34 & 21.6 \\
\hline OCN 2933 & 0.937 & 0.95 & 4.2 & 34.7 \\
\hline OCN 3142 & 0.857 & 0.9 & 3.8 & 26.0 \\
\hline OCN 3160 & 1.056 & 1 & 4.5 & 32.3 \\
\hline OCN 3241 & 1.09 & 0.95 & 4.1 & 30.1 \\
\hline OCN 3437 & 0.35 & 0.4 & 4.1 & 43.4 \\
\hline OCN 3446 & 1.801 & 1.8 & 5.85 & 26.7 \\
\hline
\end{tabular}

Table 3

CHEMICAL COMPOSITION [\%] OF SAMPLESUSED

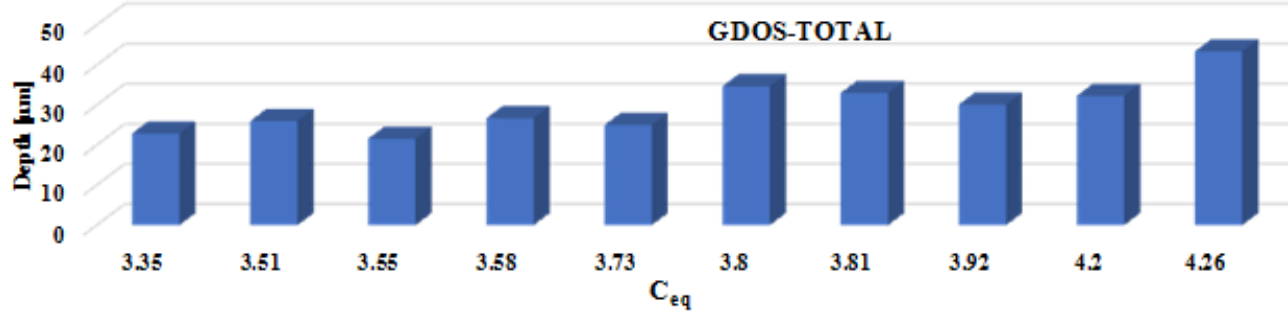

Fig. 22 The TOTAL depth of Nitrogen (GDOS TOTAL) diffusion according to the $\mathrm{C}_{\mathrm{eq}}$

The depth of the white layer was measured with the Image Analysis System (IAS) outfitted with Buehler OmniMet Enterprise image analysis software. The results obtained as an average of 25 measurements, are sown in table 3, as well as both GDOS-S1 and GDOS-S2, in order to be compared.

\section{Results and discussions}

In order to study the influence of chemical composition in the case of grey castiron on the depth of the white layer the dependence of these data was graphically represented by histogram in figure 21 . The values for the layers are presented in table 3, as well as for the Nitrogen diffusion.

In order to study the influence of the chemical composition in the case of grey cast iron on the total depth of diffusion of nitrogen (GDOS-TOTAL) the dependence of these data was graphically represented by histogram in figure 22.

\section{Conclusions}

The conclusions of this experimental research are:

- for grey castiron non-alloyed with equivalentcarbon in the range $3-4.5 \%$, the depth of the white layer does not correlate with the chemical composition of these materials.

- for grey castiron non-alloyed with equivalent carbon in the range $3-4.5 \%$, the depth of nitrogen diffusion is directly proportional to the content of carbon equivalent that can be considered linear.

- the spectral analysis allowed a precise assessment of the diffusion profile, concentration based on the diffusion depth, for the chemical elements used to achieve the enrichment of superficial layers on relatively small depths of up to about 100 microns.

The thermo-chemical treatment of oxy-nitrocarburizing contributes to the improvement of surface characteristics $[1,2,6,11]$ of alloys in the Fe-C system. Corrosion resistance increases considerably $[2,8]$, being directly 
proportional to the thickness of the white layer, comparable to the resistance provided by other protection methods such as zinc coating. Experimental determinations on samples made of oxy-nitrocarburized cast iron revealed a very good corrosion resistance, up to 200 hours without corrosion or oxidation up to a maximum of $5-10 \%[2,6]$. This property is explained by the presence in the superficial layer of magnetite and iron nitride $[4,6]$.

\section{References}

1.BOICEA, N., ABRUDEANU, M., BOICEA, G.M., A new approach for improving the lifetime of some parts made of cast iron and steel, using superficial treatments. Automotive and future technologies, Conat 2010, The 11-th international Congress.

2.BOICEA, N., ABRUDEANU, M., DUCU, C., Experimental researches concerning the influence of the oxynitrocarburizing thermochemical treatment over the structure and corrosion resistance of C40 steel. The Annals of Dunarea De J os University of Galati, ISSN 1453-083X, Fascicle IX Metallurgy and Materials Science, 100-104.

3.MITELEA, I., BORDEASU, I., MICU, L.M., CRACIUNESCU, C.M., Microstructure and Cavitation Erosion Resistance of the X2CrNiMoN225-3 Duplex Stainless Steel Subjected to Laser Nitriding, Rev. Chim. (Bucharest), 68, no. 12, 2017, p. 2992.

4.*** Fundamentals of Nitriding and Nitrocarburizing, ASM Handbook, Volume 4A, Steel Heat Treating Fundamentals and Processes, 2013, pp. 619-646.

5.NIKOLOVAL, M., NIKOLOV, D., DERIN B., YANKOV E., Effect of vacuum oxy-nitrocarburizing on the microstructure of tool steels: an experimental and modeling study, MATEC Web of Conferences, 2017, pp.1-2.
6.CALIARI, D., TIMELLI, G., An Investigation into the Effects of Different Oxy-Nitrocarburizing Conditions on Hardness Profiles and Corrosion Behavior of $16 \mathrm{MnCr} 5$ Steels. International J ournal of Metallurgical \& Materials Engineering, ISSN: 2455-2372, Volume 1, 2015, p.110.

7.WOEHRLE, T., LEINEWEBER, A., MITTEMEIJER, E., The shape of Nitrogen concentration depth profiles in gamma prime layers growing on alfa iron substrates; The thermodynamics, Metallurgical and Materials Transactions, vol. 43A, 2012, pp. 610-618.

8.WOEHRLE, T., LEINEWEBER, A., MITTEMEIJ ER, E., Microstructural and phase evolution of compound layers growing on alpha iron during gaseous nitrocarburizing, Metallurgical and Materials Transactions A, vol. 43, 2012, pp. 2401-2413,

9.MEDEIROS, J.L., Applying Oxi-nitrocarburizing surface strengthening process to corrosion prevention in MIM 17-4 PH Stainless Steels, Revista Espacios, Vol. 36, 2015, p. 21.

10.ROLINSKI, E., KONIECZNY, A., SHARP, G., Influence of nitriding mechanisms on surface roughness of plasma and gas nitrided/ nitrocarburized gray cast iron, Heat Treating Progress, vol. 3, 2007, pp. 39-46.

11.ROLINSKI, E., KONIECZNY, A., SHARP, G., Nature of surface changes in stamping tools of gray and ductile cast iron during gas and plasma nitrocarburizing, Journal of Materials Engineering and Performance, vol. 1059, 2009, pp. 1-8.

12.NIKOLOVA, M., DANEV, M.P., DERMENDJ IEV, I., GOSPODINOV, D., Vacuum Oxynitrocarburization of ultra-fine electrolytic iron, Procedia Engineering, 2011.

13.FLODSTROM, I., Nitrocarburizing and High Temperature Nitriding of Steels in Bearing Applications. Master of Science Thesis, Chalmers University Of Technology Göteborg, Sweden, 2012, pp. 8-58.

14.CZERWINSKI, F., Thermochemical Treatment of Metals, 2016, pp 92-95.

$\overline{\text { Manuscript received: } 14.02 .2018}$ 